\title{
Positive Charge
}

National Cancer Institute

\section{Source}

National Cancer Institute. Positive Charge. NCI Thesaurus. Code C81172.

Having a deficiency of electrons; having a higher electric potential. 